\title{
AGROCLIMATIC RISK ZONING OF PASSION FRUIT (Passiflora edulis Sims) IN THE HYDROGRAPHIC BASIN OF PARANÁ RIVER III, BRAZIL
}

\author{
Nathan Felipe da Silva Caldana \\ Universidade Estadual de Londrina, Londrina, PR, Brasil. \\ nathancaldana@gmail.com \\ Luiz Gustavo Batista Ferreira \\ Instituto Agronômico do Paraná, Londrina, PR, Brasil. \\ luiz.gustavo@agronomo.eng.br \\ Alan Carlos Martelócio \\ Instituto Agronômico do Paraná, Londrina, PR, Brasil. \\ amartelocio@agronomo.eng.br \\ Pablo Ricardo Nitsche \\ Instituto Agronômico do Paraná, Londrina, PR, Brasil. \\ pablo@iapar.br \\ Jorge Alberto Martins \\ Universidade Tecnológica Federal do Paraná, Londrina, PR, Brasil. \\ imartins@utfpr.edu.br
}

\begin{abstract}
Brazil is the largest producer and consumer of passion fruit in the world. Fruticulture is a prominent segment of Brazilian agriculture. Despite recent technological and scientific advances, the climate is among the most important variable in crops productions. In this context, agroclimatic zoning should be one of the first information to consider before starting the cultivation of a particular crop. The purpose of this paper was to perform agroclimatic risk zoning for passion fruit (Passiflora edulis Sims) in the basin of Parana river 3, located in Parana state, South of Brazil. For this we used meteorological data from 43 stations with historical series between from 1976 to 2019 . The analysis of agroclimatic risk was based on the species requirements, such as rainfall, annual water deficit, annual average temperature, sunshine and the risk of frost. The occurrence of frost was the most limiting factor for production in the region. This meteorological factor restricted planting in the central-eastern portion of the basin. In other areas, the risk is present, however the suitability for the passion fruit planting was guaranteed.
\end{abstract}

Keywords: Climate aptitude. Climate variability. Agricultural Planning.

\section{ZONEAMENTO DE RISCO AGROCLIMÁTICO DO MARACUJAZEIRO (Passiflora edulis Sims) NA BACIA HIDROGRÁFICA DO RIO PARANÁ 3, BRASIL}

\section{RESUMO}

O Brasil é o maior produtor e consumidor mundial de maracujá. A fruticultura é um segmento de destaque da agricultura brasileira. Apesar dos recentes avanços tecnológicos e científicos, o clima está entre as variáveis mais importantes na produtividade agrícola. Nesse contexto, o zoneamento agroclimático deve ser uma das primeiras informações a serem consideradas antes de iniciar o cultivo de determinada cultura. Dessa forma, o objetivo desse trabalho foi realizar o zoneamento de risco agroclimático para o maracujazeiro (Passiflora edulis Sims) na bacia do Rio Paraná 3, estado do Paraná. Para isso foram utilizados dados meteorológicos de 43 estações com recorte temporal de 1976-2019. A análise do risco agroclimático foi pautada nas exigências da espécie, sendo estas, precipitação, deficiência hídrica anual, temperatura média anual, insolação e o risco de geada. A ocorrência de geadas foi o fator mais limitante para a produção na região. Esse fator meteorológico restringiu o plantio na 
porção centro-leste da bacia. Nas demais áreas, o risco de geadas é presente, assim mesmo, existe a aptidão climática para o cultivo de maracujazeiro.

Palavras-chave: Aptidão climática. Variabilidade Climática. Planejamento Agrícola.

\section{INTRODUCTION}

Brazil is the largest producer and consumer of passion fruit in the world (FALEIRO and JUNQUEIRA, 2016; FAO, 2019). Fruticulture is an agricultural activity that has a major contribution to national economic development. Being a segment of agriculture, it is immersed in the risks and uncertainties that the meteorological and climatic elements bring, causing variability in production and sensitivity in the management of fruit species (MUSTAFA et al., 2018; OLIVEIRA et al., 2018; SOMBOONSUKE et al. (2018; TAYT'SOHN et al., 2018; AGOVINO et al., 2019). Knowing the characteristics and peculiarities of each climate and soil, will help in the choice of crop and decision making, the search for higher incomes and lower losses. Among the agrometeorological information employed in agricultural planning, agroclimatic zoning is the most known and the most important (CARAMORI et al., 2008; RICCE et al., 2014; SANTI et al., 2018).

Passion fruit cultivation is relevant for creation of jobs in the countryside, in the sector of sale of inputs, in agroindustries and in cities, besides being important option of income generation, being great option for fruit growers, as it generates weekly income for several months, with different market and valueadded options (LIMA et al., 2017; BEZERRA et al., 2019). Brazil is the largest producer and consumer of passion fruit, reaching approximately 1 million tons per year (FALEIRO et al., 2019).

Passion fruit cultivation has been constantly fluctuating in planted area, production and productivity throughout the country. This is due to high production costs, climatic variations, inadequate fertilization, and the incidence of pests and diseases (COSTA et al., 2012; MOREIRA et al., 2019; ROSADO et al., 2019). Low productivity usually reverts to low profitability, discouraging many producers to stay in business. In this sense, it is necessary to study alternatives that promote the increased profitability of this crop, and being the meteorological variables responsible for $80 \%$ of the variability of production (CARAMORI et al., 2008), identifying their patterns and variability are fundamental for the production. The Paraná state is located in the subtropics of Brazil, with warm summer and cold winter (CARAMORI et al., 2008), being fundamental studies of this genesis for agricultural planning and decision making on agroclimatic zoning. Establishing agricultural planning and more cost-effective models is essential for profitability and does not undermine the resource-intensive environment.

The purpose of this work was to perform climatic risk agricultural zoning for passion fruit in the basin of Paraná river 3 , a drainage area on the left bank of the Itaipú reservoir, between the rivers Iguaçu and Piquiri.

\section{MATERIAL AND METHODS}

\section{Climate Variability}

In order to analyze climate variability and define the climate risk zoning, data from meteorological stations distributed around the basin were surveyed. The database comprises six stations from IAPAR - Instituto Agronomico do Paraná (Brazil), during the interval from 1976 to 2018; 10 from SIMEPAR Sistema Meteorológico do Paraná (Brazil), between the interval from 2000 to 2018, and, 27 stations from Águas Paraná (Brazil) between the interval from 1976 to 2019, according to the Figure 1. 
Figure 1 - Hypsometry and stations location, in the basin.

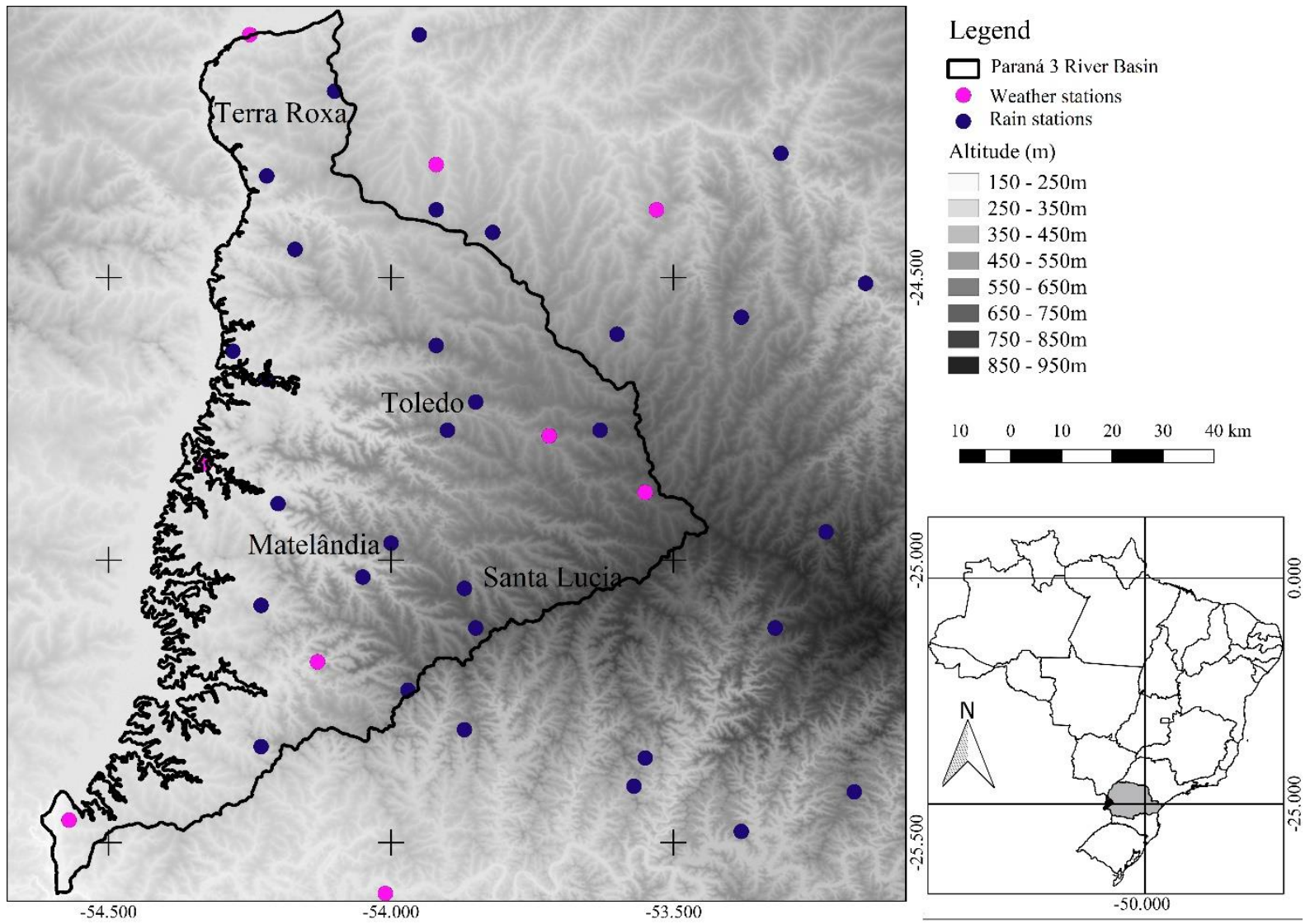

Adapted and organized by the authors (2019).

To complement the rainfall variability analysis and to identify the best time for fruit planting and the detection of climatic extremes risks, we used Box Plot graphs or box diagram. The main feature obtained from its use, is to provide a quick view of data distribution. If the distribution is symmetrical the box is balanced with the median positioned in the center of it. For asymmetric distributions, there is an imbalance in the box with respect to the median.

Box plots represent five value classifications. Outliers are divided into outliers (values above the maximum, but not extreme) and extremes, with any values exceeding Q3 + 1.5 (Q3 - Q1) or less than Q1 - 1.5 (Q3 - Q1). The highs and lows are considered the highest values in the series, but they are not extreme or discrepant. Inside the box are classified three quartiles with $25 \%$ of the data each, in addition to the median value, equivalent to the second quartile, or $50 \%$ of the data (LEM et al., 2013).

The Shuttle Radar Topography Mission (SRTM) base, at 30 m resolution (MIRANDA, 2005), was used together positioning to correct the influence of the topography on temperature. This method is needed to spatialize and regionalize data to areas that do not have temperature data with greater accuracy.

Multiple linear regression equations were applied for the spatialization of the average temperature and frost data measured at the meteorological stations. The applied equation is given by equation 1 :

$$
\mathrm{y}=\mathrm{a}+\mathrm{b} \cdot \text { lat }+\mathrm{c} \text {.long }+\mathrm{d} \text {. alt }
$$

Where $a, b, c, d$ are regression coefficients, and lat, long, and alt represent the latitude, longitude and altitude, respectively (RICCE et al., 2014). This mathematic formula was applied in Qgis geoprocessing 
software over the SRTM file, making it possible to generate maps, with spatial resolution of $30 \mathrm{~m}$ (MIRANDA, 2005).

The method used for the probability of frost was based on the historical minimum temperature series recorded within the meteorological shelter. The probabilities of values equal to or lower than $1.0^{\circ} \mathrm{C}$ were determined and then also adjusted to the equation previously mentioned for the temperature.

The Climatological Water Balance was obtained by the method of Thornthwaite and Mather (1955), using the equation with the values of several meteorological variables and the available soil water capacity proportional to the effective depth of the roots of the analyzed species. The monthly average rainfall data (extracted from the monthly totals of each year) and the monthly average temperature (extracted from the monthly averages of the daily values of each year) were considered. Then, potential evapotranspiration (PET) was calculated according to the Thornthwaite method (Equation 2, 34 and 5). First, the standard potential evapotranspiration (PET, mm / month) was calculated by the empirical formula:

$$
\begin{gathered}
\text { For: } 0<\mathrm{Tn}<26,5^{\circ} \mathrm{C}(2) \\
\text { PET }=16\left(10 \frac{\mathrm{Tn}}{\mathrm{I}}\right)^{\mathrm{a}}(3) \\
\text { i) } \quad \text { For: } \mathrm{Tn} \geq 26,5^{\circ} \mathrm{CTn}^{2}(4) \\
\text { PET }=-41585,+3224, \mathrm{Tn}-43,0 \mathrm{Tn}^{2}(5)
\end{gathered}
$$

Where: Tn - average temperature of month $n\left(n=1\right.$ is January, $n=2$ is February, etc), in ${ }^{\circ} C$; and $I$ is an index that expresses the heat level of the region.

The value of I depends on the annual temperature cycle, integrating the thermal effect of each month, being calculated by the formula (equation 6 ):

$$
\mathrm{I}=12(0,2 \mathrm{Ta})^{1,514}(6)
$$

The exponent "a", being a function of $\mathrm{I}$, is also a regional thermal index, and is calculated by the expression (equation 7):

$$
a=0,49239+1,7912 \times 10^{-2} I-7,71 \times 10^{-5} I^{2}+6,75 \times 10^{-7} I^{3}(7)
$$

The PET value represents the total monthly evapotranspiration that would occur under the thermal conditions of a standard 30-day month, and each day with 12 hours of photoperiod (N). Therefore, PET should be corrected for $\mathrm{N}$ and the number of days in the period (Equation 6).

$$
\operatorname{COR}=\left(\frac{N}{12}\right)\left(\frac{N D P}{31}\right)(8)
$$

\section{Agroclimatic risk zoning}

The risk factors selected for agricultural climate risk zoning were:

a) Annual average insolation (la): Data from the historical series of five IAPAR sunshine insolation stations, measured by means of the heliograph, were used to estimate the annual mean sunshine. Annual average totals were interpolated by Inverse Distance Weighting (IDW) across the basin. Fitness was determined by the following category: High Risk: Less than 2,200 hours (FALEIRO and JUNQUEIRA, 2016; FALEIRO et al., 2019).

b) Annual average rainfall: Monthly and annual rainfall data from 27 series of rainwater basin stations were selected. The obtained results were interpolated in a geographic information system for the generation of the maps with the regionalization of the data through the IDW. It was considered: High Risk: annual precipitation below $700 \mathrm{~mm}$ and as Low Risk above 
1,000 to $2,000 \mathrm{~mm}$ annually well distributed during the year (FALEIRO and JUNQUEIRA, 2016; FALEIRO et al., 2019).

c) Annual Water Deficiency (AWD): It was estimated according to the method of Thornthwaite and Matter (1955), and obtained by calculating the normal climatological water balance for the meteorological stations. The value of $100 \mathrm{~mm}$ we used for the available water capacity in the soil, considering that the passion fruit root system explores a depth of more than $0,40 \mathrm{~m}$ of soil profile (LUCAS et al., 2018). The results obtained were interpolated in the free software Qgis 2.18 Las Palmas - Geographic Information System (GIS) for the generation of the annual water deficit maps. The following thresholds were considered for the risk of water deficiency: High Risk: AWD>100 mm, and Low Risk: AWD $<100 \mathrm{~mm}$ (FALEIRO and JUNQUEIRA, 2016; FALEIRO et al., 2019).

d) Average annual temperature (Ta): Meteorological data from historical series of average temperatures observed inside meteorological shelters were used to estimate the average annual temperature. Using the Ta value, regression was applied as a function of latitude, longitude and altitude for the whole basin. The risk classes defined for Ta were: High Risk: below $19^{\circ} \mathrm{C}$; Medium Risk: between $19^{\circ} \mathrm{C}$ and $21^{\circ} \mathrm{C}$ and Low Risk: greater than $21^{\circ} \mathrm{C}$ (FALEIRO and JUNQUEIRA, 2016; FALEIRO et al., 2019).

e) Frost risk: Minimum temperature meteorological data from the 13-season historical series we used, taking into account occurrences of $2^{\circ} \mathrm{C}$ or below observed within the meteorological shelter to calculate the risk of frost. The probabilities of annual occurrence were calculated and correlated with altitude and latitude, obtaining a regression equation for the risk of frost. Using adjusted regressions, values greater than $20 \%$ were considered as high risk (FALEIRO and JUNQUEIRA, 2016; FALEIRO et al., 2019).

f) Annual average insolation: Were used insolation data from five weather stations of IAPAR, verified by heliograph, to estimate the annual average insolation. Then, the data were interpolated by IDW for all area of the basin. The apt for passion fruit cultivation was determined for areas with insolation higher than 2000 annual hours (FALEIRO and JUNQUEIRA, 2016).

For the creation of thematic maps and the final zoning map in Qgis software, firstly the numerical values of the weather stations were transformed into points according to the geographical coordinates of the stations. After that the edaphoclimatic requirements of the passion fruit specie were used to make the data spatialization. It was made the delimitation of the representative bands of the passion fruit climate requirements. Thus, the station values were replaced by "1. Apt" or "2. Restricted" according to the physiological requirements for each meteorological variable analyzed.

The next step was to combine the matrix images. Each pixel was assigned with the values "1" or "2", as already highlighted. If the combination for a point was filled only with values "1" the region was classified as apt. If it has a value of "2" it will be restricted by a given variable. If two or more "2" values were assigned, the location was classified as unapt.

Then, the standardization of the pixels by classifications was performed by dissolving the vector classes. In this way, the agroclimatic zoning classes were grouped, thus creating a regionalization of suitability for each species. The final map of the agroclimatic zoning of each crop provide an estimate of the representative area of each risk class, indicating if its cultivation is suitability or not for the site.

\section{RESULTS AND DISCUSSIONS}

The biological water demand of passion fruit crops is approximately $2,500 \mathrm{~mm}$ during the entire cycle, which can last up to 24 months, and each crop phase (initial phase, flowering, and production) has a different water demand and require good rainfall distribution. Passion fruit cultivation depending only on natural rain conditions can undergo some kind of water stress during drought periods. Normally, the species is produced 
in Brazil mostly under irrigation (FALEIRO and JUNQUEIRA, 2016; FALEIRO et al., 2019). However, with $1,500 \mathrm{~mm}$ of rain well distributed throughout the year can guarantee the production of passion fruit.

Analysing the climatological monthly precipitation (Figure 2), were identified annual regular precipitation distribution. Only the months of July and August in municipalities of Matelândia, Santa Lúcia and Toledo were verified medians below $100 \mathrm{~mm}$, however, for the station of Terra Rocha was verified medians under $100 \mathrm{~mm}$ in June. All stations analysed in this study exhibited medians greater than $700 \mathrm{~mm}$. Considering these information, there is not risk for passion fruit crop cultivation.

According to the average annual rainfall of all stations in the region (Figure $3 a$ ), the entire region is suitable to grow passion fruits. The northern portion of the basin, near the municipalities of Guaíra and Terra Roxa, has an average rainfall of 1,580-1,600 mm. However, years with precipitation less than $1,100 \mathrm{~mm}$ can happen frequently, especially in this area, which would be a threat to passion fruit cultivation.

Figure 2 - Average monthly rainfall in the Basin of Paraná river 3.

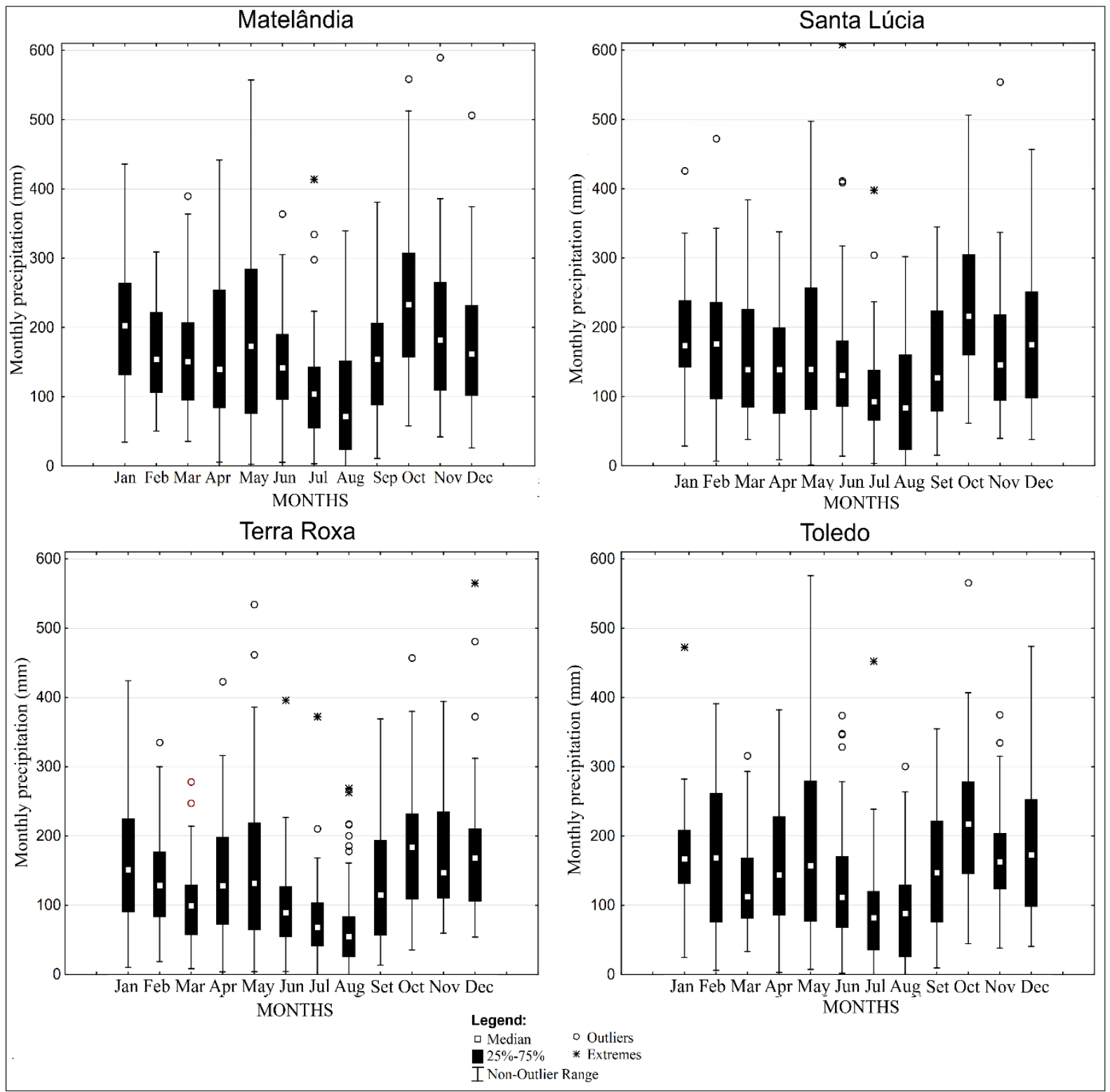

Data source - Águas Paraná, IAPAR and SIMEPAR (2019); Organization: Authors (2019). 
Nathan Felipe da Silva Caldana

Luiz Gustavo Batista Ferreira Alan Carlos Martelócio

Agroclimatic risk zoning of passion fruit (Passiflora edulis Sims) in the hydrographic basin of Paraná River III, Brazil

Pablo Ricardo Nitsche Jorge Alberto Martin

Figure 3 - a) Annual average rainfall; b) Annual average temperature; c) Frosts risks; d) Annual average insolation in basin of Paraná river 3 for passion fruit.

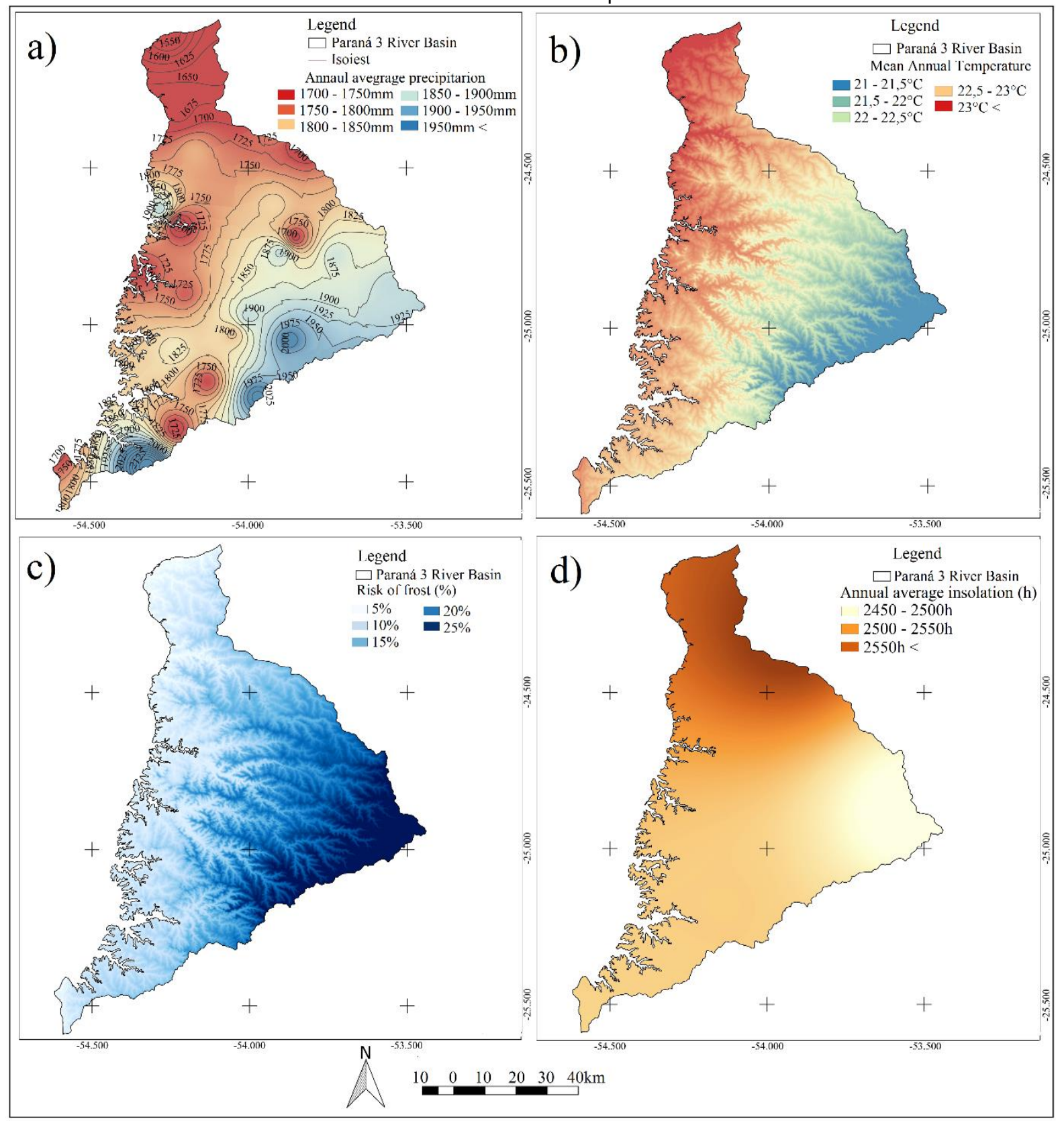

Data source - Águas Paraná, IAPAR and SIMEPAR (2019); Organization: authors (2019).

The municipality of Terra Roxa presented more than $25 \%$ of the years from 1976 to 2019 with less than $1,400 \mathrm{~mm}$ annual precipitation, not presenting inadequacy for cultivation. However, proper water management is necessary and the farmer can apply irrigation, especially during spring and summer, seasons with risk of long periods with water deficit. The region with the lowest risk of water deficit was Matelândia, even presenting some drought occurrence.

Water deficiency is detrimental in all biological stages of passion fruit development, but if it coincides with the flowering and early fruit development peaks, it will cause greater losses with reduced yield potential. During the vegetative phase, water deficit may result in reduced leaf area, which also limits the potential yield of the plant (FALEIRO and JUNQUEIRA, 2016; FALEIRO et al., 2019). 
The passion fruit water requirement was also assessed by the long term soil water budget (Figure 4). It was found that in Cascavel, São Miguel do Iguaçu and Toledo had no water deficiency in any month due to water balance, while Assis Chateabreand presented only $1.2 \mathrm{~mm}$ in March. Foz do Iguaçu and Guaíra presented water deficiency in March with higher values, being 22 and $37 \mathrm{~mm}$, respectively. The replacement in Guaíra is completed only in May.

Figure 4 - Long term soil water budget for passion fruit crop in the basin of Paraná river 3.

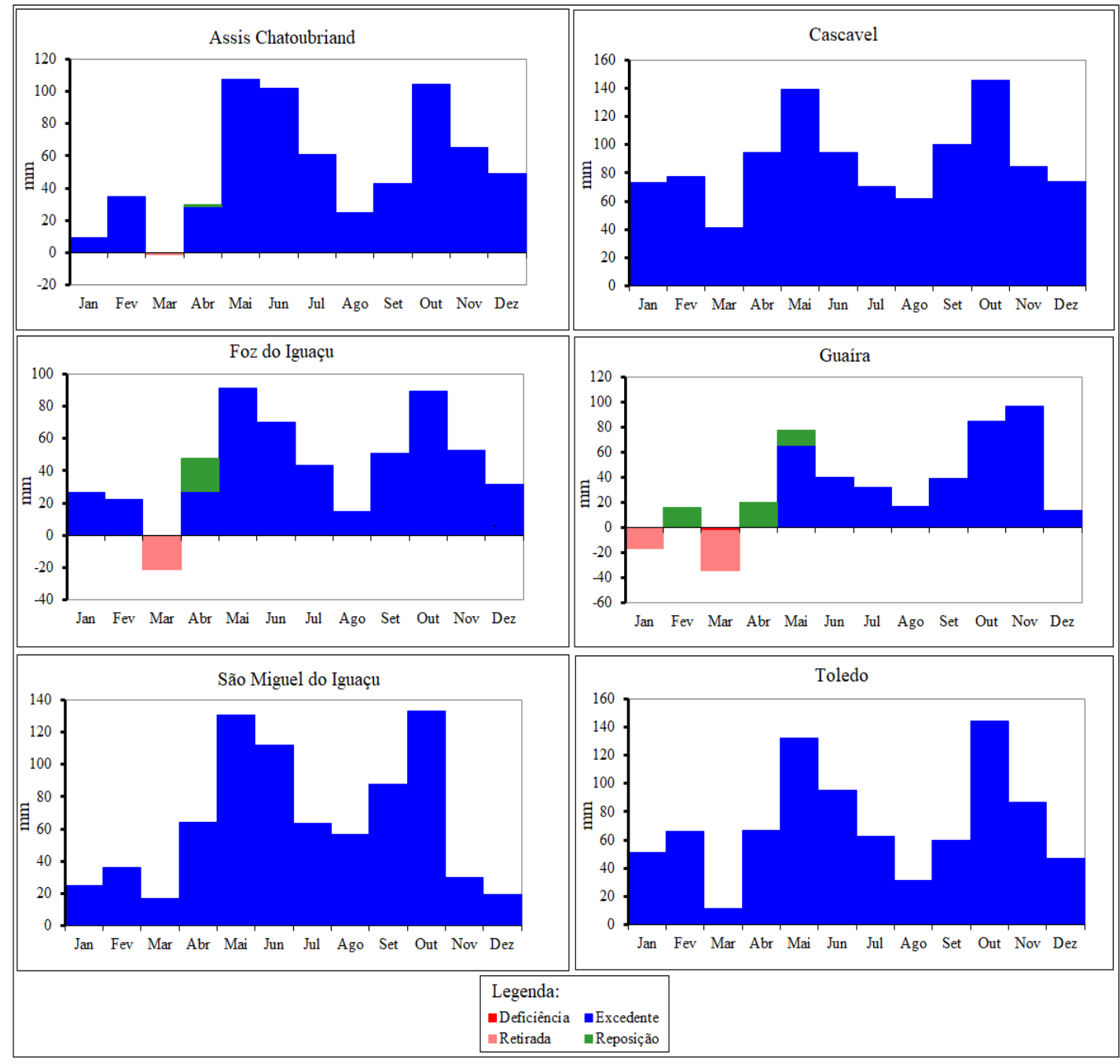

Data source - Águas Paraná, IAPAR and SIMEPAR (2019); Organization: authors (2019).

As the risk assessed was accumulated $100 \mathrm{~mm}$ annually, no stations exhibited risk for passion fruit crop cultivation. In Guaíra that presented greater deficiency the accumulated was $56 \mathrm{~mm}$. The extracts show less favorable water balance in the months from January to April, due to high temperatures and increased evapotranspiration.

Thus, farmers should pay close attention to the cultivations during this period, and in extreme cases of water deficiency, supplementary water must be applied through irrigation. The AWD - Annual Water Deficiency, in these months was not limiting for the establishment of the crop in the region, only the planting period should be adapted to escape drought periods.

The average temperature between $21^{\circ} \mathrm{C}$ and $25^{\circ} \mathrm{C}$ is considered the most favorable to passion fruit plant growth (FALEIRO and JUNQUEIRA, 2016; FALEIRO et al., 2019). The whole region showed suitability for this meteorological variable (Figure $3 b$ ). The highest area of the basin in the Cascavel 
region had the lowest average temperatures, around $21^{\circ} \mathrm{C}$, not restricting production. The edges of the valleys were also restricted, with average values of $21.5^{\circ} \mathrm{C}$. Already the southern, western and northern portion, closest to the Paraná River channel showed aptitude, with average values above $22^{\circ} \mathrm{C}$. The highest average temperatures were observed in the Guairá region, in the extreme north of the basin, reaching over $23^{\circ} \mathrm{C}$ (Figure $3 b$ ).

Places subject to cold winds and frost are limiting to the passion fruit crop. Cold winds and frost cause the leaves to burn, reducing the photosynthesis area and, consequently, the production (SENTELHAS et al., 1996). The risk of frost is present throughout the region, even if to a lesser extent in the area with lower altitudes, close to the Paraná River gutter (Figure 3c).

Passion fruit produces more in regions with 2,200 or more hours of light per year. The sour passion fruit blooms much more intensively, if grown in regions or at times of the year with 11 or more hours of light per day. The region has minimal sunstroke in the eastern portion of the basin, with an average of 2450 hours of sunshine per year (Figure 3d), thus not restricting production.

In the final map of passion fruit agroclimatic zoning (Figure 5) it can be observed that the portion with lower altitudes in the north, west and south regions presented favorable conditions for passion fruit production in all analyzed variables. In the central portion, from north to south of the basin was identified a marginal region for production, with restriction by the frost factor, since all other factors showed aptitude. Since frost is the main limiting factor, passion fruit can be cultivated in this area of the basin, though it is subject to greater risks. The producer should avoid the valley regions, end of the slope, and give preference to cultivation in areas not very steep, to facilitate the flow of cold air. Preferably, the top of the hills and the half slopes should be used, mainly exposed northwards, avoiding the exposure to the stormy and freezing systems, which come from the south of the continent, known as cold fronts.

Figure 5 - Agricultural Climate Risk Zoning of the passion fruit (Passiflora edulis Sims) in the basin of Paraná river 3.

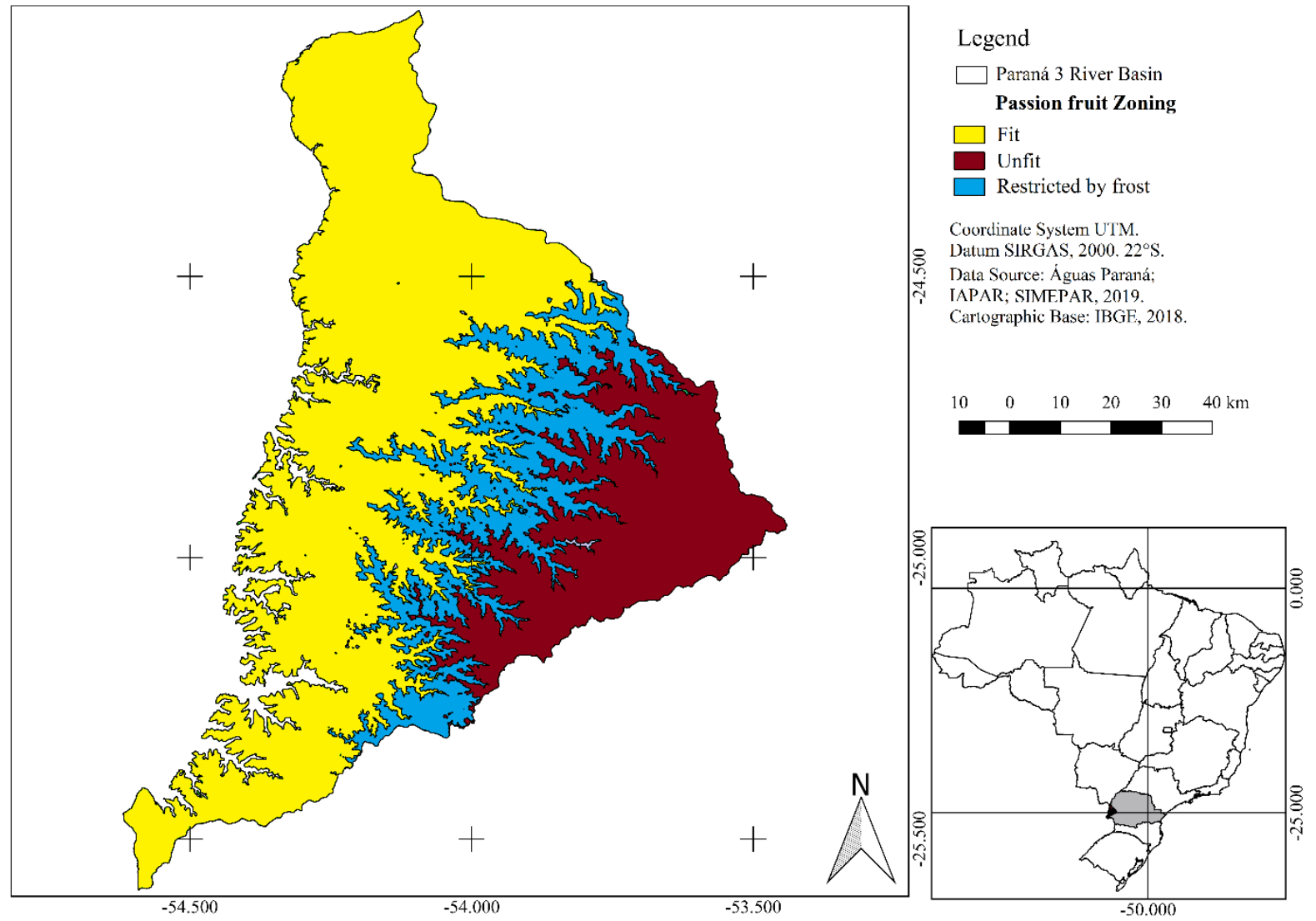

Organization - Authors (2019). 
The apt area for passion fruit cultivation is equivalent to $57,5 \%$ of the area or 460.000 ha, while the inapt area represents only $28,7 \%$ of the area of the basin (Table 1 ).

Table 1 - Distribution by area of agroclimatic aptitude.

\begin{tabular}{cccc}
\hline Zoning division & $\mathbf{K m}^{2}$ & Hectare & \% Basin area \\
\hline Fit & $4,600 \mathrm{~km}^{2}$ & $460.000 \mathrm{ha}$ & $57,5 \%$ \\
Unfit & $2,300 \mathrm{~km}^{2}$ & $230.000 \mathrm{ha}$ & $28,75 \%$ \\
Restricted & $1,100 \mathrm{~km}^{2}$ & $110.000 \mathrm{ha}$ & $13,75 \%$ \\
\hline
\end{tabular}

Org - authors, 2020.

The methodology of agroclimatic zoning does not eliminate the climatic risks, but presents the most favorable conditions for the development of passion fruit crops. Agroclimatic risk zoning is an important tool to provide greater security in decision-making, agricultural planning and climate change scenarios, especially in the basin of Paraná river 3.

\section{CONCLUSIONS}

- The basin of Paraná river 3 has regions with low climate risk for passion fruit crop, especially in areas with lower altitudes.

- Precipitation and water balance were favorable in all scenarios tested. However, in summer or long periods with no rainfall, the producer might use irrigation.

- Frosts are the most limiting factor for passion fruit production in the region. The area of the greater risks of occurrences of frost is in the Central-East area of the basin

- Management techniques must be taken to avoid frosts damage. Hence, areas with higher incidence of the phenomenon must be avoided to ensure greater success in passion fruit cultivation in the region.

\section{REFERENCES}

AGOVINO, M. et al. Agriculture, climate change and sustainability: The case of EU-28. Ecological Indicators, v. 105, p. 525-543, 2019. https://doi.org/10.1016/i.ecolind.2018.04.064

ÁGUAS PARANÁ. Sistema de Informações Hidrológicas. Relatório de Alturas de Precipitação (diário). Available in: < http://www.aguasparana.pr.gov.br/pagina-264.html > Access 15 mar. 2019.

BEZERRA, A. D. M. et al. Agricultural area losses and pollinator mismatch due to climate changes endanger passion fruit production in the Neotropics. Agricultural systems, v. 169, p. 49-57, 2019. https://doi.org/10.1016/..agsy.2018.12.002

CARAMORI, P. H. et al. Zoneamento agroclimático para o pessegueiro e a nectarineira no Estado do Paraná. Revista Brasileira de Fruticultura, v. 30, n. 4, p. 1040- 1044, 2008. https://doi.org/10.1590/S0100-29452008000400033

COSTA J. L. et al., Effect of selection on genetic variability in yellow passion fruit. Crop Breeding and Applied Biotechnology, v. 12, 253-260, 2012. https://doi.org/10.1590/S1984-70332012000400004

FALEIRO, F. G.; JUNQUEIRA, N. T. V. Maracujá. Embrapa Cerrados. Ministério da Agricultura, Pecuária e Abastecimento, 2016.

FALEIRO, F. G. et al. Expedição Safra Brasília: Maracujá: prospecção de demandas para pesquisa, extensão rural e políticas públicas baseadas na adoção e no impacto de tecnologias. Embrapa Cerrados-Livro técnico (INFOTECA-E), 2019.

FAO - Food and Agriculture Organization of the United Nations. Passion Fruit Production. Available in: < http://www.fao.org/countryprofiles/index/en/?iso3=BRA > Access 12 oct. 2019.

$\begin{array}{lllll}\text { Caminhos de Geografia } & \text { Uberlândia-MG } & \text { v. 21, n. } 77 & \text { Out/2020 } & \text { p. 85-95 }\end{array}$


IAPAR - Instituto Agronômico do Paraná. Estações Meteorológicas:dados diários. 2020. Available in: < http://www.iapar.br/modules/conteudo/conteudo.php?conteudo=889 > Access 15 mar. 2019.

LEM, S. et al. The heuristic interpretation of box plots. Learning and Instruction, v. 26, p. 22-35, 2013. https://doi.org/10.1016/j.learninstruc.2013.01.001

LIMA, L. K. S. et al. Initial vegetative growth and graft region anatomy of yellow passion fruit on Passiflora spp. rootstocks. Scientia horticulturae, v. 215, p. 134-141, 2017. https://doi.org/10.1016/j.scienta.2016.12.001

LUCAS, A. A. T. et al. Características da distribuição radicular de maracujazeiro sob fertirrigação. Irriga, v. 17, n. 2, p. 245, 2018. https://doi.org/10.15809/irriga.2012v17n2p245

MIRANDA, E. E de; (Coord.). Brasil em relevo. Campinas: Embrapa Monitoramento por Satélite. Campinas, 2005. Available in < https://www.cnpm.embrapa.br/projetos/relevobr/download/ > Access 12 oct. 2019.

MOREIRA, R. A. et al. Rentabilidade do Maracujazeiro-Amarelo com Redução do Espaçamento de Cultivo. Revista Ciência Agrícola, v. 17, n. 1, p. 23-30, 2019. https://doi.org/10.28998/rca.v17i1.7001

MUSTAFA, A. et al. Effects of Spatial Planning on Future Flood Risks in Urban Environments. Journal of Environmental Management, v. 225, p. 2018. https://doi.org/10.1016/j.jenvman.2018.07.090

OLIVEIRA, A. et al. Impact of food matrix components on nutritional and functional properties of fruitbased products. Current Opinion in Food Science, v. 22, p. 153-159, 2018. https://doi.org/10.1016/i.cofs.2018.04.002

QGIS. Sistema de Informação Geográfica livre e aberto - Versão 2.18 Las Palmas. 2020. Available in < https://www.qgis.org/pt_BR/site/forusers/visualchangelog218/index.html > Access 19 oct. 2019.

RICCE, W. da S. et al. Zoneamento agroclimático da cultura do abacaxizeiro no Estado do Paraná. Semina: Ciências Agrárias, v. 35, n. 4, p. 2337-2346, 2014. https://doi.org/10.5433/16790359.2014v35n4Suplp2337

ROSADO, R. D. S. et al. Genetic Diversity of Sour Passion Fruit Revealed by Predicted Genetic Values. Agronomy Journal, v. 111, n. 1, p. 165-174, 2019. https://doi.org/10.2134/agronj2018.05.0310

SANTI, A. et al. Impacto de cenários futuros de clima no zoneamento agroclimático do trigo na região Sul do Brasil. Agrometeoros, v. 25, n. 2, p. 303-311, 2018. https://doi.org/10.31062/agrom.v25i2.26167

SENTELHAS, P.C et al., Temperatura letal de diferentes plantas frutíferas tropicais. Bragantia, v. 55, n. 2, p. 231-235, 1996. https://doi.org/10.1590/S0006-87051996000200004

SIMEPAR - Sistema Meteorológico do Paraná. Estações Meteorológicas: dados diários. 2020. Available in: < http://www.simepar.br/prognozweb/simepar/dados_estacoes/ > Access 15 mar. 2019.

SOMBOONSUKE, B. et al. Farmers' perceptions of impacts of climate variability on agriculture and adaptation strategies in Songkhla. Kasetsart Journal of Social Sciences, v. 39, n. 2, p. 277-283, 2018. https://doi.org/10.1016/j.kjss.2018.05.006

TAYT'SOHN, F. C. O. Assessing sugarcane expansion to ethanol production under climate change scenarios in Paranaíba river basin-Brazil. Biomass and Bioenergy, v. 119, p. 436-445, 2018. https://doi.org/10.1016/j.biombioe.2018.10.003

THORNTHWAITE, C. W.; MATHER, J. R. The water balance. Centerton: Drexel Institute of Technology, Laboratory of Climatology, 1955. 104p. Publications in climatology, v. 8, n. 1, 1955.

Recebido em: 10/12/2019

Aceito para publicação em: 09/09/2020 